\title{
Migratory transient osteoporosis: atypical migration to the bilateral knee after childbirth
}

\author{
Gezici-geçici osteoporoz: Doğum sonrass iki taraflı dize atipik yayllım \\ Gülnur Tasçı Bozbaş, Gülcan Gürer, Ömer Faruk Şendur, Aslı Gül Alkan \\ Department of Physical Medicine and Rehabilitation, Medical Faculty of Adnan Menderes University, Aydın, Turkey
}

Received / Geliş tarihi: August 2015 Accepted / Kabul tarihi: November 2015

\begin{abstract}
Transient osteoporosis is a rare disorder, characterized by bone marrow edema. It is particularly seen in the last trimester of the pregnancy and remission occurs spontaneously at the postpartum period. This disorder frequently affects the hip joint, while it may rarely migrate to the knee, ankle, and the foot joints. In this article, we report a 35-year-old female case who had transient osteoporosis of the hip at the last trimester of her pregnancy and showed migration to the bilateral knee after childbirth. While spontaneous recovery of the disorder in the postpartum period was expected, transient osteoporosis interestingly advanced to her knee joints in our case. To the best of our knowledge, this is the first case of the migration of transient osteoporosis to the knee joint in the postpartum period.
\end{abstract}

Keywords: Bilateral knee; pregnancy; regional migratory osteoporosis; transient bone marrow edema; transient osteoporosis.

\section{$\ddot{O Z Z}$}

Geçici osteoporoz, kemik iliği ödemi ile karakterize nadir bir hastalıktır. Özellikle gebeliğin son trimesterinde görülür ve doğumla birlikte spontan olarak iyileşir. Bu hastalık genellikle kalça eklemini etkilerken, nadiren diz, ayak bileği ve ayak eklemlerine yayılım gösterir. $\mathrm{Bu}$ yazıda, gebeliğinin son trimesterinde kalçada geçici osteoporoz gelişen ve doğum sonrası iki taraflı diz eklemlerine yayılım gösteren 35 yaşında bir kadın olgu sunuldu. Hastalığın postpartum dönemde spontan iyileşmesi beklenirken, olgumuzda ilginç bir şekilde geçici osteoporoz diz eklemine yayıldı. Bildiğimiz kadarıyla, bu postpartum dönemde geçici osteoporozun diz eklemine yayılım gösterdiği ilk olgudur.

Anahtar sözcükler: İki taraflı diz; gebelik; bölgesel yayılan osteoporoz; geçici kemik iliği ödemi; geçici osteoporoz.

Transient osteoporosis (TO) is a rare self-limiting disease, characterized by bone marrow edema (BME). ${ }^{[1]}$ It was first described in 1959 by Curtiss and Kincaid in pregnant women in their third trimester. ${ }^{[2]}$ The term "transient osteoporosis" was first used in 1968 by Lequesue. ${ }^{[3]}$ Transient osteoporosis is a disorder which primary affects women in their third trimester of pregnancy. However, it may also be seen in middle aged men and non-pregnant women. ${ }^{[4]}$ Typically, its course involves unilateral or bilateral hip joints. But, it may also affect knee, ankle and foot joints. ${ }^{[5,6]}$ Rarely, the disorder may start from one joint and migrate to others. In this article, we presented an interesting case of TO, which started with involvement of the hip joint in a pregnant woman in her third trimester and continued with dissemination to bilateral knee joints in the postpartum period. It is the first time in the literature that a case was presented where the disorder showed migration to other joints after childbirth.

\section{CASE REPORT}

A 35-year-old female patient was admitted to our outpatient clinic with the complaint of right hip pain, which started in the last month of her pregnancy and continued after childbirth. The patient's pain had progressively increased, making her unable to walk without support. She gained a total of 26 kilos during her pregnancy. No trauma, fever or other systemic complaints were present in the patient's medical 


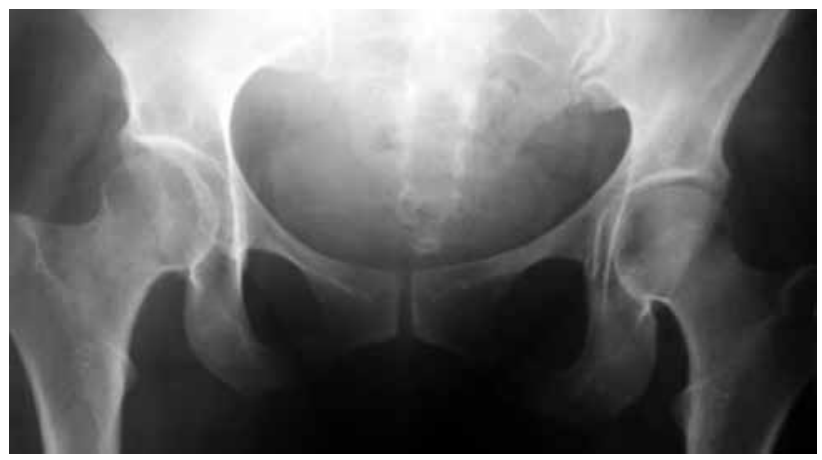

Figure 1. Direct radiography of the hip.

history. History of use of steroids or similar drugs was not present. Her calcium intake was insufficient and she did not take calcium supplements. A written informed consent was obtained from the patient.

During her physical examination, her right hip movements were limited and painful. Her pregnancy follow-up was normal and Tests of Reading Comprehension (TORCH) tests were also negative. In laboratory investigations, hematological, biochemical and serological test results were normal. Inflammation markers, vitamin $\mathrm{D}$ level, electrolytes, thyroid and parathyroid function tests were completely normal. Direct radiograph of the hip determined osteopenia of the right femur head and neck (Figure 1). In magnetic resonance imaging (MRI) of the right hip, hypodense changes in $\mathrm{T}_{1}$-weighted sequences, and hyperdense changes in $\mathrm{T}_{2}$-weighted and short $\mathrm{T}_{1}$ inversion recovery (STIR) sequences were detected in the right femur head and neck, which were consistent with BME

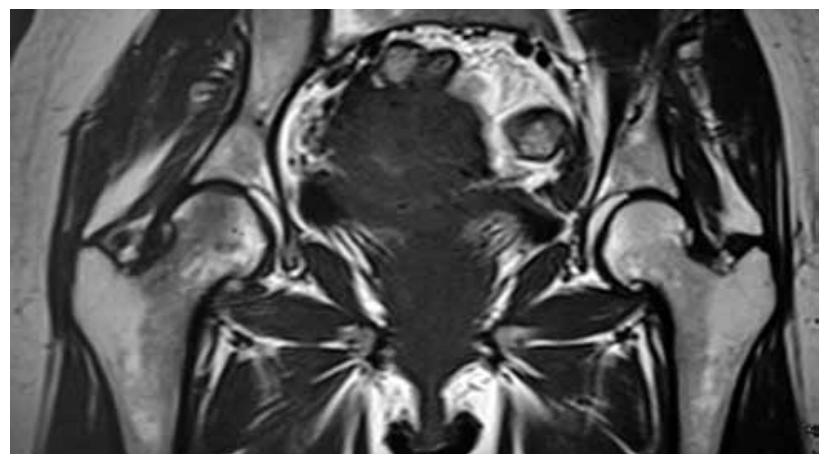

Figure 2. Coronal $\mathrm{T}_{1}$-weighted magnetic resonance imaging of the hip; bone marrow edema in the right femur head and neck.

(Figure 2). The bone mineral densities of the right hip and lumbar regions were evaluated as normal (respectively; T-scores: -0.6, Z-scores: 0.4 and T-scores: 0.8 and Z-scores: 1.4 ). The patient was diagnosed as TO and was advised to use a crutch in order to lessen the burden, to use analgesics when needed and to perform isometric exercises.

Two months later, the patient was readmitted to outpatient clinic with bilateral knee pain. During the physical examination, her bilateral knee movements were painful, and no inflammation was present. Her laboratory investigations revealed normal results. In her MRI, signal changes in medial condyles of both femurs, which were consistent with BME, were identified (Figure 3).

As a result, TO with migratory characteristics was diagnosed. Again, she was advised to limit her burden, to do isometric exercises and to use analgesics
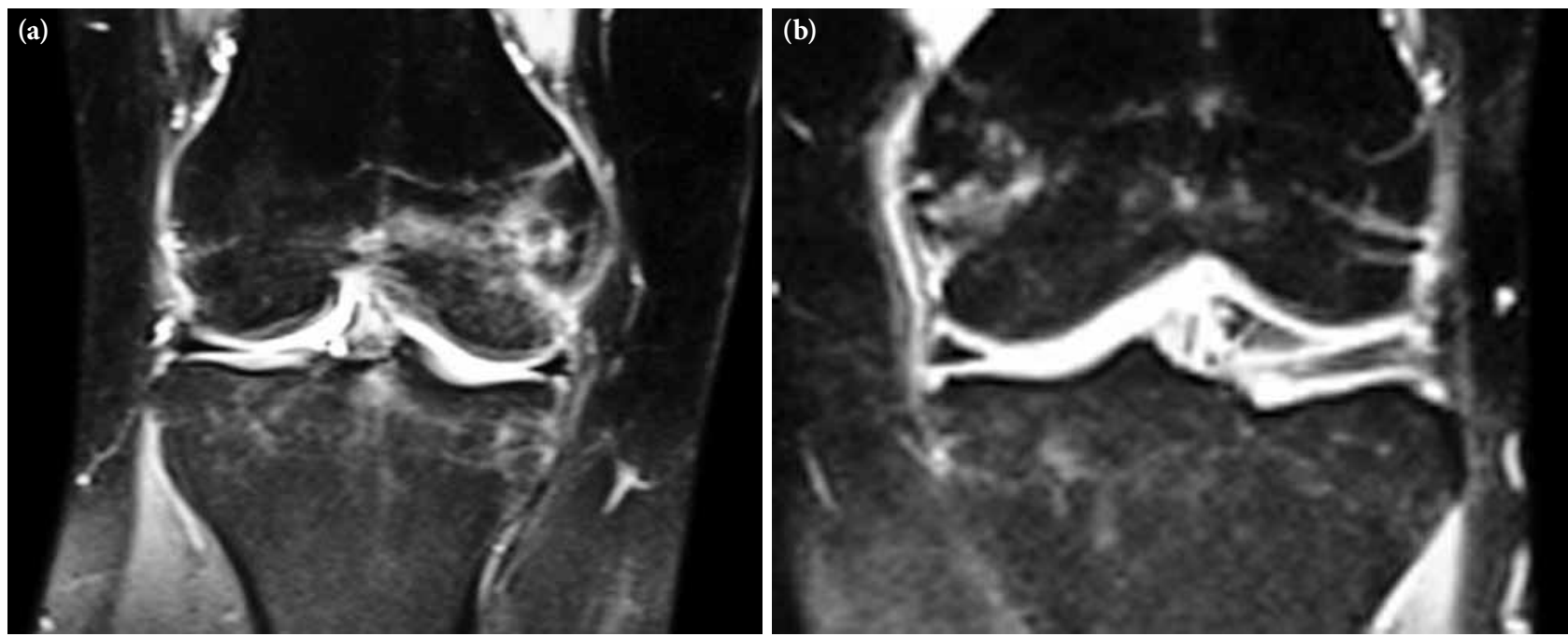

Figure 3. Coronal short $T_{1}$ inversion recovery magnetic resonance imaging of the right (a) and left (b) knee; bone marrow edema in the medial femoral condyles. 
when needed. The patient's symptoms were completely resolved at the end of three months. The MRI of the hip at this period was completely normal and in her knee MRI, the severity of BME decreased significantly.

\section{DISCUSSION}

Transient osteoporosis is a rare disorder, characterized by BME. ${ }^{[7]}$ Although particularly seen in pregnant women during the third trimester, it may also be detected in young men. ${ }^{[7-9]}$ The hip joint is most frequently affected $(76 \%) .{ }^{[10]}$ This is followed by lower extremity joints such as knee, ankle and foot joints. The migration of the disease is generally from proximal joint to distal joint. ${ }^{[1]}$ Similarly in our case, the symptoms first appeared in hip joint during the last trimester of pregnancy and migrated to her knees. The most frequent secondarily involved joint is the knee. ${ }^{[11]}$ Bilateral knee involvement, as in our case is quite rare and only three cases were reported prior to this case report. ${ }^{[3,5,7]}$

The pathogenesis of the disorder is still not clear. Genetic predisposition, local circulatory disorders, compression of obturator nerve, medullary hypertension of bone, small vessel ischemia, subperiosteal and subchondral fat embolism and pregnancy-related hormonal factors are implicated etiologically. ${ }^{[1]}$ Increased body weight during pregnancy increases the load on the hip joint and the increasing size of the uterus increases the pressure within the abdomen. These two causes may both lead to TO by disturbing the pelvic venous return. ${ }^{[12]}$ Frost suggested "the regional acceleratory phenomenon (RAP)" in the pathogenesis of the disorder. ${ }^{[12,13]}$ This is a situation in which the regional blood flow, cellular metabolism and turnover and tissue remodeling become 2-10 times faster due to a stimulus.

It was suggested that, during pregnancy, the overload due to weight gain and the hormonal status affect the micro injury, resulting in induction of $\mathrm{RAP}^{[12]}$ This situation explains why TO is manifested in weight-bearing joints and particularly in their weight-bearing parts. ${ }^{[14]}$ In our case also, the excessive weight gain during pregnancy might have led to the development of TO by both disturbing the venous return and activating RAP, related to micro injury. In a third trimester pregnant woman, approximately $30 \mathrm{mg}$ of calcium is lost due to mineralization of fetal skeleton. With insufficiency of intake calcium added to the scene, a negative balance is created and this may trigger TO. ${ }^{[15]}$ Insufficient calcium intake was seen in our case, which increased risk factors for this disorder. $^{[1,14]}$
Transient osteoporosis can be recovered from spontaneously ${ }^{[15]}$ It has also been reported that TO was improved by the termination of pregnancy in severe cases that do not respond to the other treatment. ${ }^{[16]}$ Interestingly in our case, a remission was not seen during the postpartum period and migration occurred other joints.

There is no specific biochemical, hematological or serological test for diagnosing TO. Magnetic resonance imaging is the most specific and sensitive diagnostic method. ${ }^{[1,17]}$ Magnetic resonance imaging findings occur within 48 hours following the onset of symptoms. In MRI, BME is typical and joint effusion may also be seen. ${ }^{[9]}$ A normal subchondral area and joint spacing are important for the differential diagnosis from other disorders. ${ }^{[9,11]}$ In our case, the MRI of hip and knees that was taken a few weeks after the onset of symptoms was determined BME, despite joint space and subchondral bone, was normal in accordance with TO.

Infection, joint inflammation, primary or metastatic malignancy, stress fractures, vascular necrosis and regional migratory osteoporosis (RMO) should be kept in mind during differential diagnosis. The separation of TO from avascular necrosis is essential for prognosis and avoidance of unnecessary therapies, such as surgical decompression or arthroplasty. Transient osteoporosis can be distinguished from avascular necrosis, which is the most frequently encountered cause of confusion, by an absence of narrowing in joint space and "doubleline" sign formed at the demarcation line. ${ }^{[1]}$ Transient osteoporosis and RMO have the same radiological and histological findings. This condition brings to mind the question: "Are TO and RMO two separate entities or different stages of the same disease?". While TO was more frequently encountered in third trimester pregnant women, RMO was a disorder which was met frequently in male patients aged 5-6 decades. ${ }^{[1,12]}$ In addition as the hip is often the first affected joint in TO, RMO frequently affected ankle, foot and knee joints at first. ${ }^{[10,11]}$ On these grounds, they are different diseases and we diagnosed our case with migratory transient osteoporosis, based on her epidemiological features and on her onset of the disorder with hip involvement. When we analyzed the published medical literature, we determined that $5-42 \%$ of cases diagnosed with TO had migratory characteristics such as in our case. ${ }^{[3,16,18]}$

Treatment of TO is conservative. The restriction of weight bearing on the involved joint can help prevent 
formation of microfractures on the joint surface which may progress to collapse. ${ }^{[1]}$ Additionally, activities which trigger pain should be avoided. During this period, treatment should be supplemented with isometric exercises. When needed, appropriate analgesics may be used, taking the pregnancy into consideration. Moreover, cases in whom iloprost (a prostacyclin analog), bisphosphonates, calcitonin or prednisolone had been used were reported. ${ }^{[1,12,19]}$ In our patient, the limitation of the burden on the affected joint and analgesics were sufficient for treatment.

In conclusion, in this article, we reported a case of TO that developed in the hip joint during the last trimester of pregnancy and showed migration to bilateral knee at postpartum period. In literature, it was expressed that TO entered into remission after childbirth in all of the reported cases of this disorder. However, in our case, TO showed migration to other joints starting from the hip in the postpartum period. Therefore, the present case showed us that TO could continue during the postpartum period. Finally, with this case it needs to be kept in mind that TO could continue after childbirth.

\section{Declaration of conflicting interests}

The authors declared no conflicts of interest with respect to the authorship and/or publication of this article.

\section{Funding}

The authors received no financial support for the research and/or authorship of this article.

\section{REFERENCES}

1. Kartal E, Sahin E, Dilek B, Baydar M, Manisali M, Kosay C, et al. Regional migratory osteoporosis: case report of a patient with neuropathic pain. Rheumatol Int 2011;31:1375-81.

2. Curtiss PH Jr, Kincaid WE. Transitory demineralization of the hip in pregnancy. A report of three cases. J Bone Joint Surg [Am] 1959;41:1327-33.

3. Ververidis AN, Drosos GI, Kazakos KJ, Xarchas KC, Verettas DA. Bilateral transient bone marrow edema or transient osteoporosis of the knee in pregnancy. Knee Surg Sports Traumatol Arthrosc 2009;17:1061-4.
4. Maliha G, Morgan J, Vrahas M. Transient osteoporosis of pregnancy. Injury 2012;43:1237-41.

5. Stamp L, McLean L, Stewart N, Birdsall M. Bilateral transient osteoporosis of the knee in pregnancy. Ann Rheum Dis 2001;60:721-2.

6. Grey A, Dalbeth N, Doyle A. Clinical images: Transient regional osteoporosis. Arthritis Rheum 2009;60:3145.

7. Charpidou T, Lang F, Langenegger T, Dedes KJ, Honegger C. Bilateral transient osteoporosis of the knee during pregnancy. Arch Gynecol Obstet 2013;287:1259-61.

8. Rozenbaum M, Boulman N, Rimar D, Kaly L, Rosner I, Slobodin G. Uncommon transient osteoporosis of pregnancy at multiple sites associated with cytomegalovirus infection: is there a link? Isr Med Assoc J 2011;13:709-11.

9. Szwedowski D, Nitek Z, Walecki J. Evaluation of transient osteoporosis of the hip in magnetic resonance imaging. Pol J Radiol 2014;79:36-8.

10. Nikolaou VS, Pilichou A, Korres D, Efstathopoulos N. Transient osteoporosis of the knee. Orthopedics 2008;31:502.

11. Cahir JG, Toms AP. Regional migratory osteoporosis. Eur J Radiol 2008;67:2-10.

12. Trevisan C, Ortolani S, Monteleone M, Marinoni EC. Regional migratory osteoporosis: a pathogenetic hypothesis based on three cases and a review of the literature. Clin Rheumatol 2002;21:418-25.

13. Frost HM. The biology of fracture healing. An overview for clinicians. Part I. Clin Orthop Relat Res 1989;248:283-93.

14. Klier I, Zoldan J, Yosipovitch Z, Gadoth N. Transient regional and migratory osteoporosis. A possible neural mechanism. Isr J Med Sci 1988;24:201-6.

15. Uzun M, Ayhan E, Beksac B, Karaman O. Regional migratory osteoporosis and transient osteoporosis of the hip: are they all the same? Clin Rheumatol 2013;32:919-23.

16. Malizos KN, Zibis AH, Dailiana Z, Hantes M, Karachalios T, Karantanas AH. MR imaging findings in transient osteoporosis of the hip. Eur J Radiol 2004;50:238-44.

17. Emad Y, Ragab Y, El-Shaarawy N, Rasker JJ. Transient osteoporosis of the hip, complete resolution after treatment with alendronate as observed by MRI description of eight cases and review of the literature. Clin Rheumatol 2012;31:1641-7.

18. Fazekas JE, Losada R, Fruauff AA, Ortiz O, Katz DS. Migratory transient osteoporosis of the hip occurring before and during pregnancy. J Women Imag 2002;4:80-5.

19. Funk JL, Shoback DM, Genant HK. Transient osteoporosis of the hip in pregnancy: natural history of changes in bone mineral density. Clin Endocrinol (Oxf) 1995;43:373-82. 